\title{
SCHEMES AND LEVELS OF STATE AID TO RAIL INDUSTRY IN EUROPE: EVIDENCES FROM A CROSS-COUNTRY COMPARISON
}

\author{
UGO ARRIGO', GIACOMO DI FOGGIA" \\ University of Milano-Bicocca, Milano, Italy
}

\begin{abstract}
The purpose of this paper is to illustrate the evolution of both schemes and levels of public support to railway sector in selected European countries. Although prior research sheds some light on this topic, more information is required to clarify national obligations under European railway liberalisation law regarding incentives toward railway undertakings. Focusing on Italy, besides the reduction of capital grants, justified by the completion of the high-speed line Turin-Milan-Naples, this paper finds an increasing support to the service operators and in the meantime a reduction of subsidies aimed at financing network operations. This shift of resources may undermine competition. The findings of this study help to fill the gap in estimating State aid to European railways.
\end{abstract}

\section{JEL CLASSIFICATION \& KEYWORDS}

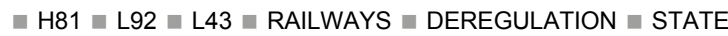
AID - TRANSPORT ECONOMICS - SUBSIDIES - EUROPE COMPETITION

\section{INTRODUCTION}

In today's fast-paced, knowledge-intensive environment, State aid control should more effectively target sustainable growth-enhancing policies while encouraging budgetary consolidation, limiting distortions of competition and keeping the single market open. Knipes (2013) provides a short outline of the historical roots of the controversial debates on the role of the State and the markets, and the organization of competition in European railroad industries. State aid is defined as an advantage in any form whatsoever conferred on a selective basis to undertakings by national public authorities. Therefore, subsidies granted to individuals or general measures open to all enterprises are not covered by this prohibition and do not constitute State aid. In 2012 The EU Commission has proposed a recast of a directive establishing a single European railway area, aiming to increase competition in the rail market by improving access to terminals and maintenance facilities and strengthening the powers of national rail regulators (Directive 2012/34/EU). However, investigations into public support measures granted to national rail carriers have recently been opened. Firms, specially incumbents, must therefore find the right balance between industrial consolidation and competition since they are not mutually exclusive while Governments shall thrive in (i) regulating the rail sector in accordance with the EU legislation which many EU countries signed up to over ten years ago, and (ii) remove other barriers to competition and service growth. Prior research has analysed the reforms (Preston, 2009), methods to explore the impact of subsidies on competition (Nitsche \& Heidhues, 2006), the effectiveness of State aid in increasing the efficiency in railways across Europe (Friederiszick, Röller, \& Schulz, 2003), train access charges

' ugo.arrigo@unimib.it

"giacomo.difoggia@unimib.it
(Knieps \& Zenhäusern, 2011), the European rail reform (Nash, 2010).

However, there may be circumstances in which more information is required to clarify national obligations under European Railway liberalisation law in relation to charging, allocation, incentives to improve performance and the permitted structure of Infrastructure Managers and Railway Undertakings. In this paper we consider the evolution of public subsidies throughout a cross-country comparison; insights from Italy, Germany, Great Britain, Sweden, and France are provided. We develop this idea in detail by analysing and combining income statements, official documents and scholar's analyses in an effort to reconstruct public subsidies to the Italian railway incumbent starting from 1992, when Ferrovie dello Stato (FS) was converted into a joint-stock company. Finally, our analysis sheds light to what extent public subsidies have been meant to grants for current expenses and grants related to assets. Data were retrieved from national incumbents and from respective regulators. The remainder of this paper is organised as follows: in the first section to introduce European legislation and guides on State aid related to railways, we then discuss steps in some European countries; this is followed by the Italian case and conclusion.

\section{Literature Review}

A number of reforms have affected the European rail market over the last two decades, Preston (2009) reviews what actual changes have occurred on the ground over this period. Friebel, Ivaldi \& Vibes (2010) estimate the effects of reforms on railroad efficiency in Europe by using a new panel data set that covers most EU countries over a period of more than 20 years. In the paper of Couto \& Graham (2009) the cost structure of the railway industry is analysed using a stochastic frontier approach. Knipes (2013) evaluates competition on the markets for rail services and public subsidies for rail infrastructures as well as subsidies for train services. Di Foggia \& Lazzarotti (2013) focus on the business implication of development policies, Szekely (2009) sheds a light on the transformation schemes in Europe so that it would be possible for countries to set up better policies. For instance the expenses of rail infrastructure costs are partly covered by the European governments and partly by the infrastructure managers through the infrastructure charges that operators pay to them for rendering services in the infrastructure they manage.

The processes of vertical and horizontal separation within the railway sector are relatively recent in many European countries, and as a result, little analytical research has been carried out on their impact (Cantos, Pastor \& Serrano, 2010). Growitsch \& Wetzel (2009) conduct a pan-European efficiency analysis to investigate the performance of European railways with a particular focus on economies of vertical integration. A key role is played by access charges for the use of the infrastructure, Andersson \& Ögren (2007) 
state that in order to achieve a competitive transport sector, infrastructure charges in the European Union should be based on short-run marginal costs. Calvo \& De Oña, (2012) study a series of national charging systems to compare track usage costs and the charges that seek to recover those costs. They also examine the pricing levels applied to railway services to study the coherence between national charging systems and the charging principle on which they are based. By the same token Beria et al., (2012) provide an analysis of the relationship between the State and the rail companies, network access conditions by operators, slot allocating and pricing schemes and how public service obligations are defined, financed and regulated. EU rules require track access charges to be set on the basis of direct/marginal costs - the cost directly incurred as a result of operating a train service. As an exception for specific investment projects only, higher charges can be set on the basis of the long-term costs of such projects, (Directive 2012/34/EU).

The topic of subsidies to European railways has been less investigated because of the disparities in management systems, access charge models and ownership of incumbent operators. Also Beria et al., (2012) argue that entry in the industry has not yet developed its full potential and highlight that an issue emerging in this research is the opposing attitude of incumbent railways against liberalisation and the role of governments in backing this behaviour. To this regard, by comparing Sweden, Great Britain and Germany, the examination of subsidy levels finds that Germany has the slowest growth in public financial support for its railway, as well as the lowest increase in fares (Nash, Nilsson \& Link, 2013) and model Nilsson et al., (2013) describe recent reforms in Sweden, and to address how the reforms have handled four critical issues for the success of the reforms: the allocation of infrastructure capacity; the provision of maintenance and terminal facilities; the access to rolling stock; and the provision of information and ticketing to travellers. Nilsson, J. E. (2002) describes the Swedish reorganisation, the subsequent process towards free entry and competition in parts of the sector and the consequences of these changes and argues that the policies have been mainly directed towards the sector's inability to recover costs.

\section{Rail subsidies in Europe}

Control of State aid in Europe has become a key element (EU Commission, 2011). In fact, it is a useful tool to protect fair competition. Holvad (2006) provides an overview of railway reforms in Europe which at EU level were initiated by Directive 91/440, he also focuses on the background to the reform process. To be compliant with EU rules, aid granted by a Member State or through State resources shall not distort competition and trade within the EU by favouring certain companies or the production of certain goods (TFEU, 2008). The report of NERA (2004) assesses the public budget contributions to the financing of railway undertakings and rail infrastructure managers, as well as to review their financial position. EU Parliament has recently proposed a recast of the first railway package, some major objectives of the proposed recast are: avoiding distortions of competition due to the use of State funds for commercial activities, eliminating conflicts of interest in the management of rail-related services and increasing their availability for new entrants as well as increasing market transparency to ensure effective competition. Over the last thirty years, the level of non-crisis State aid has decreased: in the 1980s the share of the total GDP intended for aid in various forms was about $2 \%$, while in 2001 about $0.6 \%$ of European GDP. The amount of subsidies to the railway sector, limited to the countries that have made available the data (Austria, Belgium, Denmark, Estonia, Spain, Finland, France, Italy, Luxembourg, Lithuania, Latvia, Portugal and Sweden), amounted to $€ 27.2$ billion. From the second half of the $90 \mathrm{~s}$ there was the introduction of the access charges for the new EU members; the experience of those EU States has been showing how their approach has been a reasonable compromise between two aims: charge systems whose first priority was favouring an efficient use of networks and, as second aim, having an adequate level of coverage of the costs of the operator.

\section{Revenues and subsidies in selected countries}

We now introduce some information about the selected countries. Table 1 contains total revenues, market revenues and revenues by subsidies. Data refer to passengers sector without distinguish between local and long distance. Values are expressed in euro cents per passenger-Km.

\begin{tabular}{|l|l|l|l|l|l|}
\hline \multicolumn{1}{|c|}{ Table 1: Revenues and subsidies per passenger-Km (€ cents) } \\
\hline & Sweden & Great Britain & Italy & France & Germany \\
\hline Subsides & 0.9 & 1.6 & 5 & 5.2 & 6.7 \\
\hline $\begin{array}{l}\text { Market } \\
\text { revenues }\end{array}$ & 10.7 & 15.6 & 7.6 & 9.9 & 8.8 \\
\hline $\begin{array}{l}\text { Total } \\
\text { revenues }\end{array}$ & 11.6 & 17.2 & 12.6 & 15.1 & 15.5 \\
\hline
\end{tabular}

Source: 2012 reports of Network Rail

\section{Great Britain}

Until the 1994-1995 reform, public financial support for the railway sector was composed of direct subsidies to British Rail (BR) and Passengers Transport Executives (PTE), as well as loans to British Rail by the National Fund Loan. The privatisation process of the railway sector has led to changes in the scheme of public funding. The subsidy levels have been set in order to allow newly established railway undertakings to obtain commercial returns, offsetting unprofitable lines. Over the years of the reform's implementation, the net funding requirement to support the industry has been reduced by the proceeds from the sale of rolling stock operating companies and the remaining assets of British Railway, the latter not related to passenger traffic. Since 1997-1998, the Government's support for the railway sector has mainly consisted of transfers provided by the Office Passenger Rail Franchising afterwards by the Solicitors Regulation Authority and finally by the Department for Transport - from grants to Passenger Transport Executives, and by a contribution to British Railway to finance its remaining activities. In the 2000s, direct government transfers to the managers of the network became increasingly important. The different categories of support are the following: (i) direct subsidies for the network operator, (ii) transfers from the central government to the train operating companies' passenger franchise agreements and performance receipts (specifications and performance awards), (iii) transfers to Passengers Transport Executives for the metropolitan rail transport, (iv) grants to freight rail transport. In the year 2010-2011, the network managed by Network Rail $(15.800 \mathrm{~km})$ hosted 514 million trains-Km, corresponding to 54.5 billion passengers $/ \mathrm{km}$ and 19.2 billion tonnes $/ \mathrm{km}$ of goods, for a total of 73.7 billion units of traffic. To this extent it is possible to figure out the following data per $\mathrm{km}$ : operating costs equal $€ 177$ while market revenues of the operator add up to $€ 165$, thus $€ 12$ represents the difference. The central Government total grant was $€ 271$ thousand-km, mainly aimed at covering the remaining costs of the operator. Dividing the total operating costs by the 
trains-Km, we calculate $€ 5.4$ total operating cost train-Km; $€ 5.1$ covered by the market revenues of the operator (of which $€ 4.3$ are from access charges and $€ 0.7$ from other revenues) and public subsidies for the difference. Since it is likely that a proportion of operating costs had been generated from the production of services not directly related to the network's traffic, we prefer to deduct from the operating costs the value of operating revenues not directly derived from the network services. We then obtain operating costs that are approximately $€ 4.7$ train- $\mathrm{Km}$, of which $€ 4.3$ are covered by the access charge revenues and the remaining $€ 0.4$ by public subsidy. Considering the total traffic unit transported (passengers kilometres more tonnes of goods $\mathrm{km}$ ), it is plausible to calculate operating costs attributable to the network totalling $€ 0.033$ cents - revenues from the market are $€ 0.03$ cents, the residue are public subsidies. In relation to the costs of the network operator, Network Rail stated in its 2012 budget, reports the continued reduction of unit costs made possible by the increase in efficiency achieved thanks to the traffic increase. The overall reduction in the unit cost in seven year is $34.6 \%$ (5.9\% per year)

\section{Sweden}

In the period before the separation of the network, until 1988, the public operator SJ (vertically integrated incumbent) was both the only interlocutor of the government for assistance in the field and the sole beneficiary of public transfers. They could: (i) purchase from the state of transportation services that were not provided by SJ because they were related to geographic areas with low demand. It is the case with Public Service Obligations - (ii) compensation for tariff awarded to support specific categories of users, (iii) financing of investments that would not have been carried out by SJ as unprofitable, (iv) cancellation of SJ debts (in favour of the State). On this last point, it should be noted that SJ could not obtain funding from the private sector but only from the State. It could be that the total debt proved stable growth over time and would make periodic culls necessary. In overall terms, during the decade preceding the reform, the various types of transfer generated an average three billion SEK annual outlay for the public purse at constant 2001 prices (300 million euro). Thanks to the 1988 reform and the stages of the subsequent years, the types of subsidy have changed. Transfers designed to cover the difference between the costs of operation and maintenance of the network and access charge revenues, together with investments for renovation of the network and new projects, were headed by Banverket, while the fees for transportation services not economically self-sufficient were directed to operators of passenger rail. A large part of the costs incurred by the management of Swedish infrastructure was directed to new investments and infrastructure renewal. From the post reform to the beginning of the 2000s, the ordinary costs of the network were about two billion SEK per year (200 million euro). The revenue from access charges covered a remarkable share when one considers the adoption of the criterion of short-run marginal cost in setting tariff. Investments improved by more than $50 \%$ throughout the last four years (2008-2011). It is therefore possible to calculate cost and unit revenues, dividing total $€$ by the network's length and traffic levels. In 2010, the Swedish railway network managed by Trafikverket $(10,000 \mathrm{~km})$, hosted 139 million train-Km, passengers and goods, and transported 11.2 billion passengers $/ \mathrm{km}$ and 23.5 billion tonnes $/ \mathrm{km}$ of goods, generating a total of 34.7 billion units of traffic. The technical productivity of the network was equal to 13,900 yearly trains-Km, corresponding to thirtynine trains daily on average. To this extent it is possible to figure out the following data per km: Operating costs equal $€ 46$, market revenues of the operator are $€ 8$, thus the difference is $€ 36$. The overall public sector costs for renovation and investment were $€ 105$ thousand. If we combine the economic data with traffic data, we obtain $€ 3.3$ operating costs of the network to train- $\mathrm{km}$ and $€ 0.5$ revenues train- $\mathrm{Km}$. In relation to units of total traffic carried, we obtain a cost of $€ 0.013$ and revenue market share to 0.02 cents.

\section{Germany}

Public subsidies to the German railway system are divided into financial support from the central government to DB Netz for investment and the local authorities responsible for charges arising from Public Service Obligations for regional transportation. Based on the data available for 2010, more than $85 \%$ of national spending provided for this purpose was granted to Deutsche Bahn. Using the data reported in Dehornoy (2011), it can be seen that the total burden for the German railway system amounted to $€ 15.9$ billion $€ 10.2$ if we exclude the federal support to BEV (Federal Railway Fund) aimed at debt management and the payment of pensions to former employees of the two railway companies of Western and Eastern Germany. Of the $€ 10.2$ billion, about $€ 4.6$ were directed to the network and $€ 5.6$ to cover the costs arising from regional rail transport. As for subsidies for the network, it should be noted that, based on German railway reform, DB Netz has to operate according to market principles and, therefore, does not benefit from public funding to cover the recurrent costs arising from the exercise. Dehornoy (2011) shows that the $€ 4.2$ billion transfers from the Bund are enough to finance most of the investments. Considering that in the same year the trains$\mathrm{Km}$ circulating on the German network were 1.06 billion, the average cost of the network operator was $€ 3.6$ train- $\mathrm{Km}$. Data show that the access charges of freight trains account for $18 \%$ of total revenues, the cost of the network and stations are $25 \%$ of revenues of the long-distance passenger segment and the cost of network and stations are $37 \%$ of segment revenues of the regional passenger segment. For all the three types of rail transport, the sum of network and station charges covers $30 \%$ of revenues. Dividing $€ 5.2$ billion of infrastructure revenue by 1.06 billion yearly train$\mathrm{Km}$, we obtain $€ 4.9$ average cost train- $\mathrm{Km}$ ( $€ 4.0$ without considering the use of stations and additional services). Dividing the net income derived from any type of traffic for its trains-Km per year, we calculate an average cost of $€ 5.3$ train-Km for regional transportation, $€ 6.2$ for long-distance and $€ 3.9$ for freight trains. The 2010 network's technical productivity was 31400 annual trains-Km, corresponding to 86 trains a day on average.

\section{France}

According to Dehornoy (2011), the total amount of subsidies to rail transport were $€ 12.9$ billion in 2010 ; $€ 9.8$ billion if we exclude the State contribution intended to supplement the pension fund of the former railway workers. Of the $€ 9.8$ billion awarded, $€ 5.2$ billion were assigned to SNCF (of which $€ 4.3$ billion were assigned to public service obligations and $€ 0.9$ billion aimed at investments), while $€ 4.6$ billion to the infrastructure manager RFF (including $€ 2.4$ billion grants for current expenses and $€ 2.2$ billion for investments). Summing up the total subsidies to the two entities, we calculate $€ 6.7$ billion for operating expenses and $€ 3.1$ billion for investments. The data from the annual report of the Comptes des transports allow us to update the analysis of public subsidies. In 2011, the total burden was $€ 12.5$ billion, which decreased to $€ 9.3$ when considered net of the State contribution to the pension fund, and $€ 5.3$ billion out of $€ 9.3$ billion were allocated to SNCF (€4.7 billion for 
public service obligations and $€ 0.6$ billion in investments), and $€ 4$ billion to the infrastructure manager. The total subsidies to the two entities - grants for current expensesamounted to $€ 7.0$ billion, those in capital account to $€ 2.3$ billion. In order to determine which types of costs are funded by State grants for current expenses and the degree of coverage of the costs of RFF guaranteed by rail access charges, it is necessary to refer to the 2011 income statement. Industrial management of RFF has been active since the ordinary expenses of operation of the network were fully covered by access charges collected for the transit of trains; of the $€ 4.5$ billion access charges, $66 \%$ relating to transport goods and passengers to the long distance borne by the railway undertakings and $33 \%$ relative to local passenger transport borne by the public sector. Considering additional $€ 0.8$ billion from other government grants and $€ 1$ billion of other incomes, the infrastructure manager fully covered all production costs. The values of cost and revenue can be associated with trains- $\mathrm{Km}$ produced in the year in order to calculate the unit values. The calculation can only be carried out for the year 2010, when the operating costs of RFF amounted to $€ 3.65$ billion compared with trains-Km outstanding of 484.8 million. The average cost train-Km of the infrastructure manager was therefore $€ 7.5$. Instead, the average cost incurred by the railways for the use of the network was $€ 8.7$ ( $€ 4.2$ billion access charges for 484.8 million trains-Km). The network's technical productivity was 15,700 annual train-Km, corresponding to forty-three daily trains. The trains-Km were 485 million. Given that they generated $€ 4.2$ billion revenues from access charges, we can infer $€ 8.7$ as average access charge train- $\mathrm{Km}$. Integrating data from Références (2012), we estimate access charges by the regional transport amounting to $€ 1.45$ billion, which corresponds to $€ 6.4$ access charge train-Km. Subtracting the total charges, we infer that the total charges paid by long-distance passenger trains and freight trains amounted to $€ 2.75$ billion. Based on current rates, it is reasonable to assume that the average value for the freight train $\mathrm{km}$ is $€ 4.6$. Based on the above assumptions, the average cost for the use of a passenger train in France would be $€ 9.4$ per $\mathrm{km}$.

\section{Italy}

The public sector has sustained rail transport in Italy with significant subsidies, which were mainly to cover the operating costs of the railway network, the cost of local rail transport and the financing of investment programmes. Cascetta, Coppola \& Velardi, (2013) present some empirical evidences on the evolution of national passenger demand before and after high-speed rail major openings, and show a significant increase of traffic volume by rail due to the introduction of high-speed rail. These findings are consistent with the need of transparency among competitors statements. A complete and accurate reconstruction of all subsidies for rail transport in Italy is, however, hampered by the absence of a dedicated body. In order to cover quite a long period - at least from the 1992 transformation of FS into a joint-stock company - we use a plurality of sources in relation to different sub-periods: (i) 1992-1995, the total annual transfer of current portion is between $€ 5.3$ and $€ 6.3$ billion, with an average annual value of $€ 5.7$ billion (Arrigo \& Di Foggia, 2013b) and (ii) 1996-2006, sharp reduction of public transfers, $€ 2.3$ billion from $€ 5.7$ granted in the previous year, a reduction of almost $60 \%$. In the following years, they return to higher values but still below the levels found before 1997. (iii) 1998-2001, the annual income statement contributions amounted to an average annual value of $€ 4.2$ billion, of which $€ 1.5$ represented by grants to the network, $€ 1.6$ from transfers in favour of unprofitable transport services and $€ 1$ billion represented by the use of the restructuring fund. (iv) 2002-2005, Annual average support (Income statement contributions) increased to $€ 4.6$ billion, mainly due to the increased use of the restructuring fund. The contribution to the exercise of the network and transport services unprofitable instead falls from $€ 3.1$ to $€ 2$.9. It also changes their distribution, with a decrease in the subsidy to the network at $€ 1.1$ billion, and an increase to $€ 1.8$ billion toward transport services. (v) 2007-09 (FS balance sheet), $€ 4.3$ billion income statement contributions emerged. (vi) 2010-2011, Total transfers (income statement contributions) declined, but it should be noted that the financial statements of the group FS lost in clarity and no longer explicitly mentioned some items representing support from the State. In the entire period of FS (1992-2011), total public support amounted to $€ 88.6$ billion (current values), corresponding to $€ 4.4$ billion annually. In addition to income statement contributions, the public sector has supported over time rail transport even with substantial contributions to investment programmes. From 1997 to 2005, the investment support was through FS capital increases signed by the Ministry of Economy. During the nine years in which this form was used, the total outlay was slightly more than $€ 15$ billion, equivalent to $€ 3.3$ billion yearly average. With the 2006 financial law, also, the State agreed to cover 13 billion of debts of FS. Since 2006, capital increasing policy has been abandoned replaced by the policy of granting direct contributions to investments. The contributions made to this qualification had achieved in the six years between 2006 and 2011 a total of $€ 21.4$ billion. Over the whole period 1997-2011, the FS grants related to capital account reached $€ 67$ billion. All through the same period, the total investment of FS added up to $€ 81$ billion. If to public grants related to capital account we add those related to grants for current expenses, amounting to $€ 60$ billion in 15 years, we obtain $€ 127$ billion total public support to $\mathrm{FS}$, corresponding to an annual average of $€ 8.5$ billion. Compared with the German

\begin{tabular}{|l|l|l|l|l|}
\hline \multicolumn{5}{|c|}{ Table 2: Subsidies to FS Group (million $€$ ) } \\
\hline & $\begin{array}{l}\text { Operating } \\
\text { grants }\end{array}$ & $\begin{array}{l}\text { Capital } \\
\text { grants }\end{array}$ & $\begin{array}{l}\text { Total } \\
\text { subsidies }\end{array}$ & $\begin{array}{l}\text { Investment } \\
\text { (FS group) }\end{array}$ \\
\hline $\mathbf{1 9 9 2}$ & 6,348 & & & \\
\hline $\mathbf{1 9 9 3}$ & 6,072 & & & \\
\hline $\mathbf{1 9 9 4}$ & 5,11 & & & \\
\hline $\mathbf{1 9 9 5}$ & 5,322 & & & \\
\hline $\mathbf{1 9 9 6}$ & 5,733 & & & \\
\hline $\mathbf{1 9 9 7}$ & 2,329 & 2,633 & 4,962 & 2,759 \\
\hline $\mathbf{1 9 9 8}$ & 4,125 & 3,068 & 7,193 & 3,394 \\
\hline $\mathbf{1 9 9 9}$ & 4,023 & 3,822 & 7,845 & 3,527 \\
\hline $\mathbf{2 0 0 0}$ & 4,207 & 3,176 & 7,383 & 3,798 \\
\hline $\mathbf{2 0 0 1}$ & 4,38 & 3,615 & 7,995 & 4,845 \\
\hline $\mathbf{2 0 0 2}$ & 5,06 & 4,078 & 9,138 & 5,504 \\
\hline $\mathbf{2 0 0 3}$ & 4,107 & 4,051 & 8,158 & 7,208 \\
\hline $\mathbf{2 0 0 4}$ & 4,948 & 2,989 & 7,937 & 8,447 \\
\hline $\mathbf{2 0 0 5}$ & 4,117 & 3,54 & 7,657 & 8,528 \\
\hline $\mathbf{2 0 0 6}$ & 3,151 & 17,951 & 21,102 & 7,263 \\
\hline $\mathbf{2 0 0 7}$ & 4,244 & 4,277 & 8,521 & 6,864 \\
\hline $\mathbf{2 0 0 8}$ & 4,366 & 3,332 & 7,697 & 6,096 \\
\hline $\mathbf{2 0 0 9}$ & 4,146 & 5,089 & 9,234 & 5,25 \\
\hline $\mathbf{2 0 1 0}$ & 3,512 & 2,294 & 5,806 & 4,143 \\
\hline $\mathbf{2 0 1 1}$ & 3,329 & 3,155 & 6,484 & 3,808 \\
\hline Total & 88,628 & 67,069 & 127,111 & 81,434 \\
\hline Yearly average & 4,431 & 4,471 & 8,474 & 5,429 \\
\hline $\mathbf{5 0 u r}:$ Auth & & & & \\
\hline
\end{tabular}

Source: Authors 
and French cases, there is a greater variability over time. It is also possible to note that in recent years, besides the reduction of capital account support, justified by the completion of the HS Turin-Milan-Naples line, there has been a growth of support for the transport services and a reduction of support for the running of the network. This shift of resources does not foster competition since public support for the network is potentially neutral in respect to operators who use it, while the one in favour of the operators creates advantage only for the operators that run it, which have not been identified so far through tender procedures capable of ensuring effective competition for the market.

\section{Discussion}

Table 3 highlights important aspects of the five rail networks: first, the extension of the different networks: Italy and Great Britain have a similar length and occurs equally between France and Germany, however, the network in the first two countries is about half if compared to the last two while the Swedish is about a third.

\begin{tabular}{|l|l|l|l|l|l|}
\hline \multicolumn{5}{|c|}{ Table 3: Derived indicators of network cost and revenues } \\
\hline & France & Germany & $\begin{array}{l}\text { Great } \\
\text { Britain }\end{array}$ & Italy & Sweden \\
\hline Network size & 30.9 & 33.7 & 15.8 & 16.7 & 10 \\
\hline $\begin{array}{l}\text { Network } \\
\text { operative cost } \\
\text { (bil.€) }\end{array}$ & 3.6 & 3.8 & 2.4 & 1.7 & 0.5 \\
\hline $\begin{array}{l}\text { Network cost } \\
\text { (th.€) }\end{array}$ & 118 & 113 & 153 & 104 & 46 \\
\hline $\begin{array}{l}\text { Total yearly } \\
\text { trains-km } \\
\text { (mil.€) }\end{array}$ & 485 & 1,06 & 514 & 324 & 139 \\
\hline $\begin{array}{l}\text { Average daily } \\
\text { trains-Km }\end{array}$ & 43 & 86 & 89 & 53 & 38 \\
\hline $\begin{array}{l}\text { Operative costs } \\
\text { trains-Km (€) }\end{array}$ & 7.5 & 3.6 & 4.7 & 5.4 & 3.3 \\
\hline Source: Authors & \multicolumn{7}{|l|}{} \\
\hline
\end{tabular}

The annual costs of rail network operations appear to be proportional to the extension of the infrastructure. If we estimate the network's costs per km we obtain analogous values for Italy, Germany and France; in fact the three countries show an average cost per $\mathrm{km}$ that range between $€ 104$ thousand in Italy and $€ 118$ thousand in France. The average cost in the Great Britain is $€ 153$ thousand, while the cost in Sweden is $€ 46$ thousand. Sweden is an interesting case that should be investigated to see how the cost advantage is a consequence of the organizational model used, featuring: public and integrated management with the management of the road network and outsourcing of maintenance and intervention on the lines that are awarded through a tenders as well as light organizational structure with few structured personnel. The network traffic levels are very different: for instance in Germany yearly train- $\mathrm{Km}$ are more than double if compared with France, although the network has a similar extension - mainly due to the high development of freight transport in Germany. In turn, trains-Km in Great Britain, which have seen a quickly growth thanks to the reform and liberalization of the market in the ' 90 s, are $60 \%$ more than in Italy and France. These specificity impact on the technical productivity of network: in Great Britain and Germany, as an average transit 90 daily trains-Km, both passenger and freight; slightly over 50 in Italy and France, a little less in Sweden. Considering the average cost per train-Km of the network (which is obtained by dividing the total annual cost for the train- $\mathrm{Km}$ ) the highest value is $€ 7.5$ in France, then comes Italy with $€ 5.4$ train- $\mathrm{Km}$ and Great Britain with $€ 4.7$ train- $\mathrm{Km}$, the latter is followed by Germany and Sweden with $€ 3.6$ and $€ 3.3$ respectively. Considering the data provided, one may note that the cost advantage of rail transport in Italy resulting from the low burden of network usage does not derive from a cost advantage of the network operator, but by the fact that the rates are properly maintained below the average cost thanks to subsidies to the network (operating grants). Image 2 shows the relationship between average costs per train $\mathrm{km}$ of the network operator and average charge applied to passenger trains. The difference between the two values is covered by public subsidies when the average access charge is less than the average cost (Sweden, Italy, and Great Britain) and is intended to finance other costs or margins of the operator in the opposite case (France and Germany).

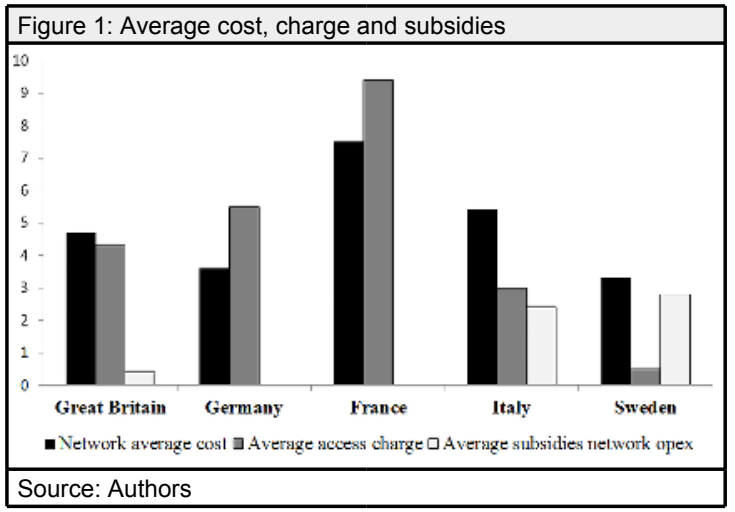

The Italian $€ 3$ average charge for the use of the network per train $\mathrm{km}$ results to be viable thanks to the presence of public subsidies covering 2.4 euro that in turn corresponds to the missing amount to cover $€ 5.4$ average cost per train $\mathrm{km}$ of the network operator. In Sweden, on the other hand higher train- $\mathrm{Km}$ subsidy, precisely $€ 2$.8, allows to apply $€ 0.5$ access charges per train-Km. The passenger rail transport in Italy has both an advantage and a weakness: the first is represented by the low cost for the use of the network, the second by the lower unit revenue by market resulting from lower average charge per $\mathrm{km}$. It is now appropriate considerate the validity of the train system regulatory assets, observing in particular who is the regulator of the sector, its level of independence from the government, the infrastructure manager and the train operators, the adequacy of its regulatory powers and of its powers of protection against the competitors. Table 4 gives the evaluations to the above listed conditions. As it can be observed, Sweden and Great Britain have the best market asset. There's a prevalence of positive evaluations in the cases of Germany, a prevalence of negative evaluations for France and Italy. As an answer against the EU remarks,

Table 4: Regulator and infrastructure manager independence

\begin{tabular}{|l|l|l|l|l|l|}
\hline & Sweden & $\begin{array}{l}\text { Great } \\
\text { Britain }\end{array}$ & Germany & France & Italy \\
\hline $\begin{array}{l}\text { Independent } \\
\text { regulator }\end{array}$ & Yes & Yes & Yes & No & No \\
\hline $\begin{array}{l}\text { Regulator with } \\
\text { sufficient } \\
\text { control powers }\end{array}$ & Yes & Yes & Yes & No & No \\
\hline $\begin{array}{l}\text { Infrastructure } \\
\text { manager } \\
\text { independent } \\
\text { from railway } \\
\text { operator }\end{array}$ & Yes & Yes & No & No & No \\
\hline Source: Authors & & & & \multicolumn{4}{|l}{} \\
\hline
\end{tabular}


France created in 2009 the Autorité de Régulation des Activités Ferroviaire.

In order to conduct more detailed considerations on the differences in unit revenues by market among the considered cases, we represent the Table 1 in a different version in which all values are recalculated by setting equal to 100 the unit revenues from the Italian market, thus taken as the value basis as in Table 5 .

\begin{tabular}{|l|l|l|l|l|l|}
\hline \multicolumn{6}{|c|}{ Table 5: Revenues and subsidies per passenger-Km, (Italy = 100) } \\
\hline & Sweden & Great Britain & Italy & France & Germany \\
\hline Subsides & 12 & 21 & 65 & 68 & 88 \\
\hline $\begin{array}{l}\text { Market } \\
\text { revenues }\end{array}$ & 140 & 204 & 100 & 129 & 114 \\
\hline $\begin{array}{l}\text { Total } \\
\text { revenues }\end{array}$ & 151 & 225 & 165 & 197 & 202 \\
\hline Source: Authors & & & & \\
\hline
\end{tabular}

As Table 5 shows, market unit revenues are higher in all countries if compared with Italy, in particular, large differences are found in Sweden and Great Britain, these countries do not strongly rely on public subsidies, slightly more elevated revenues in Germany $(+14 \%)$ and in France $(+29 \%)$, but one should consider that in France more than $60 \%$ of passengers use high-speed trains.

\section{Conclusion}

In this paper we have examined State aid to rail transport in some European countries, considering that it should more effectively target sustainable growth-enhancing policies while encouraging budgetary consolidation. Competition policy and legislation aim to ensure that rail transport markets operate efficiently. This is especially important when newly competitive markets are emerging as a result of liberalisation processes. The potential for rail transport growth throughout Europe is huge, but it needs a concerted effort by governments, regulators, incumbents and others to make it happen. European markets for passenger rail transport services were highly regulated for a number of decades. In recent years, however, efforts have intensified to make this market segment more competitive (Beck, 2011). Subsidies to rail transport are justified by objectives of social welfare: capital grants to network are aimed at increasing infrastructural facilities, operating grants to network are aimed at Increasing their use by those who offer transport services and finally subsidies related to service operators are aimed at Increasing demand from users. Shifting from a normative analysis to positive analysis, we note that not all grants awarded are used to increase the infrastructural facilities, the provision of transport services or related demand from consumers. Subsidies can be provided by public decision-makers in excessive quantities to meet the needs or may not be completely designed by those who perceive them to meet the needs for which they were awarded. In the presence of at least one of these phenomena, the following consequences could arise under specific conditions: (i) inefficient financing both of infrastructure managers and service operators (ii) cross-subsidisation of transport services (provided under a monopoly regime) thus receiving public aid and services performed in the open market that should not receive subsidies. The present study has also shown that the total revenue of rail passengers from the market and from public subsidies related to trains- $\mathrm{Km}$ result higher in Italy than in other analysed European countries. Further research is needed to shed light to what extent public subsidies are meant to grants for current expenses and grants related to assets across European incumbents within the railway sector, in fact, a recent communication of the Commission has set out a State aid reform programme in the communication on State aid modernisation (COM/2012/0209 final). The modernisation has three main, closely linked objectives: Foster growth in a strengthened, dynamic and competitive internal market, focus enforcement on cases with the biggest impact on the internal market and streamlined rules and faster decisions. The findings of this study help to fill the gap in estimating subsidies to European railway operators and to facilitate the implementation of the fourth railway package.

\section{References}

Andersson, H., \& Ögren, M. (2007). Noise charges in railway infrastructure: A pricing schedule based on the marginal cost principle. Transport Policy, 14(3), 204-213. Doi: 10.1016/j.tranpol.2007.01.002.

Arrigo U., \& Beccarello M. (2000), II trasporto ferroviario. La convergenza europea nel settore pubblico [Railway transport. European convergence in the public sector]. Franco Angeli, Milano.

Arrigo, U., \& Di Foggia, G. (2013a). Competition and Pricing of Essential Inputs: the Case of Access Charges for the use of the Italian Rail Infrastructure. UTMS Journal of Economics, 4(3), 295-307.

Arrigo, U., \& Di Foggia, G. (2013b). Gli aiuti di Stato al settore ferroviario nell'Unione Europea [State Aid to Railways in Europe]. Working paper of Di.SEA.DE. retrieved December 17, 2013, from http://boa.unimib.it/bitstream/10281/49292/1/ArrigoDi\%20Foggia\%20AIUTI\%20DI\%20STATO\%20U.E.\%20ALLE\%20F ERROVIE.pdf

Beck, A. (2011). Barriers to entry in rail passenger services: empirical evidence for tendering procedures in Germany. European Journal of Transport and Infrastructure Research, 11(1).

Beria, P., Quinet, E., de Rus, G., \& Schulz, C. (2012). A comparison of rail liberalisation levels across four European countries. Research in Transportation Economics, 36(1), 110-120. Doi: 10.1016/j.retrec.2012.03.014.

Calvo, F., \& De Oña, J. 2012. Are rail charges connected to costs?. Journal of Transport Geography, 22, 28-33. Doi: 10.1016/j.jtrangeo.2011.11.004.

Cantos, P., Pastor, J. M., \& Serrano, L. (2010). Vertical and horizontal separation in the European railway sector and its effects on productivity. Journal of Transport Economics and Policy, 44(2), 139-160.

Consolidated versions of Treaty on the Functioning of the European Union, (2008). Article 107 (ex Article 87 TEC). Official Journal of the European Union, C 115, $0001-0388$

Cascetta, E., Coppola, P., \& Velardi, V. (2013). High-Speed Rail Demand: Before-and-After Evidence from the Italian Market. disPThe Planning Review,49(2), 51-59. doi:10.1080/02513625.2013. 826539.

Couto, A., \& Graham, D. J. (2009). The determinants of efficiency and productivity in European railways. Applied Economics, 41(22), 2827-2851. doi:10.1080/00036840801949782.

Cowie, J. (2010). Subsidy and productivity in the privatised British passenger railway. 7 th International Conference on Competition and Ownership in Land Passenger Transport.

DB (2012). 2012 Financial report. Retrieved October 12, 2013, from www.deutschebahn.com/file/3897424/data/2012_gb_dbfinance.pdf.

Dehornoy, J. (2011). The evolution of public funding to the rail sector in 5 European countries - a comparison. In Fourth Annual Competition and Regulation in Network Industries (CRNI) conference.

Directive 2012/34/EU of the European Parliament and of the Council of 21 November 2012 establishing a single European railway area 2011 OJ L 343/32.

Di Foggia, G., \& Lazzarotti, V. (2013). Business Implications of Local Development Policies: the Case of Dubai and the Travel Industry. Theoretical and Empirical Research in Urban Management, 8(1), 5-18. 
European Commission, (2012). Communication from the Commission to the European parliament, the council, the European economic and social committee and the committee of the regions. EU State Aid Modernisation (SAM) [2012].

European Commission (2012). State aid Scoreboard, Report on State aid granted by the EU Member States. Brussels. Retrieved October 10, 2013, from http://ec.europa.eu/competition/state_aid/ studies_reports/studies_reports.html.

EUROSTAT (2013). Railway transport. Retrieved August, 3, 2013, from http://epp.eurostat.ec.europa.eu/portal/page/portal/transport/ data/database.

Eurostat (2012). Energy, transport and environment indicators. European Union, Luxembourg.

Friebel, G., Ivaldi, M., \& Vibes, C. (2010). Railway (de) regulation: a European efficiency comparison. Economica, 77(305), 77-91. doi:10.1111/j.1468-0335.2008.00739.x.

Friederiszick, H. W., Röller, L. H., \& Schulz, C. C. (2003). Evaluation of the effectiveness of State aid as a policy instrument: The Railway Sector. [Draft version]. Retrieved September, 2, 2013, from idei.fr/doc/conf/rai/papers_2003/friederiszick.pdf.

FS (2012). 2012 Financial Statements. Retrieved from http://www.fsitaliane.it/fsi-en/Investor-Relations/FinancialStatements.

Growitsch, C., \& Wetzel, H. (2009). Testing for economies of scope in European railways: an efficiency analysis. Journal of Transport Economics and Policy, 43(1), 1-24.

Knieps, G. (2013). Competition and the railroads: A European perspective. Journal of Competition Law and Economics, 9(1), 153-169. doi:10.1093/joclec/nhs040.

Knieps, G., \& Zenhäusern, P. (2011). The reform process of the railway sector in Europe: A disaggregated regulatory approach (No. 141). Diskussionsbeiträge/Institut für Verkehrswissenschaft und Regionalpolitik. Retrieve July, 1, 2013, from http://portal.unifreiburg.de/vw/files/files-publikationen/disk/disk141.

Mizutani, F., \& Uranishi, S. (2011). Does vertical separation reduce cost? An empirical analysis of the rail industry in OECD countries. Discussion paper.

Nash, C. (2010). European rail reform and passenger services-the next steps. Research in Transportation Economics, 29(1), 204-211. doi:10.1016/j.retrec.2010.07.025

Nash, C., Nilsson, J. E., \& Link, H. (2013). Comparing three models for introduction of competition into railways. Journal of Transport Economics and Policy (JTEP), 47(2), 191-206.

NERA (2004). Study of the financing of and public budget contributions to Railways, report to the European Commission - DG Tren, London, $136 \mathrm{p}$.

Network rail (2012). 2012 Network Rail Limited Annual Report and Accounts. Retrieved August, 5, 2013, from http://www.networkrail.co.uk/Annual_report_archive.aspx.

Nilsson, J. E., Pyddoke, R., Hulten, S., \& Alexandersson, G. (2013). The Liberalisation of Railway Passenger Transport in Sweden. Journal of Transport Economics and Policy (JTEP), 47(2), 307-312.

Nilsson, J. E. (2002). Restructuring Sweden's Railways; The Unintentional Deregulation. Swedish Economic Policy Review, 9(2).

Nitsche, R., Heidhues, P. (2006). Study on methods to analyse the impact of State aid on competition. Economic papers $n^{\circ} 244$, European Commission. Brussels, Belgium.

OECD-ECMT, (2008). International Transport forum. Charges for the Use of Rail Infrastructure. Retrived July, 7, 2013 from http://www.internationaltransportforum.org/Pub/pdf/08RailCharges. pdf.

Preston, J. (2009). Trends in European railways over the last two decades. Built Environment, 35(1), 11-23. doi:10.2148/benv.35.1.11.

Références, (2012). Les transports en 2011 (tome 1) [Transports in 2011 (part 1)]. Retrieved from http://www.statistiques.developpementdurable.gouv.fr/fileadmin/documents/Produits_editoriaux/Publicatio ns/References/2012/CCTN\%20ann\%C3\%A9e\%202011\%20ed.\%2 02012/CCTN-juin2012.pdf.
SNFC (2012). 2012 Financial report. retrieved September, 8, 2013 from www.sncf.com/sites/default/files/reports/sncf_group.fy2012 financial_report_02.18.2013.pdf.

SJ (2012). 2012 Annual report. Retrieved September, 8, 2013, from www.sj.se/sj/jsp/polopoly.jsp?d=120\&a=8175\&l=en.

Szekely, B. (2009). Liberalisation of the railway industry in Europe: toward a sustainable system through process view. International Journal of Sustainable Economy, 1(2), 167-185. doi:10.1504/IJSE.2009.023046. 